\title{
An unusual cause of acute abdomen in children: Mesenteric pseudocyst in the ileum
}

\section{Çocuklarda nadir bir akut batın sebebi: ileumda mezenterik psödokist}

\author{
Mehmet Uysal ${ }^{1 *}$ \\ ${ }^{1}$ Karaman State Hospital, Karaman, Turkey \\ *Corresponding author: Mehmet Uysal E-mail: drmyzuysal3@gmail.com ORCID: 0000-0003-1561-6601 \\ Received: 14 April 2020 Accepted: 23 May 2020
}

\begin{abstract}
Intraabdominal cysts and pseudocysts are unusual lesions. Mesenteric cysts in the pediatric age group are more common in boys [62.5\%] and most cases are under 10 years of age. Mesenteric cysts are often asymptomatic. Mesenteric cysts rarely recur after removal and patients have a good prognosis. The most common surgical procedure in treatment is excision during laparotomy. We present the surgical method that we apply to the unusual case of ileum mesenteric cyst, which constitutes the clinical picture of the acute abdomen in an 11 years old boy, in the light of the literature.
\end{abstract}

Keywords: pseudocyst, children, ileum

\section{öz}

Karın içi kistler ve psödokistler nadir lezyonlardır. Pediatrik yaş grubundaki mezenterik kistler erkeklerde [\%62,5] daha sık görülür ve çoğu vaka 10 yaşından küçüktür. Mezenterik kistler sıklıkla asemptomatiktir. Çıkarıldıktan sonra mezenterik kistler nadiren tekrarlar ve hastalar iyi bir prognoza sahiptir. Tedavide en sık uygulanan cerrahi işlem laparotomi sırasında eksizyondur. 11 yaşındaki erkek çocuğunda akut karın klinik tablosunu oluşturan nadir görülen ileum mezenter kist olgusuna uyguladığımız cerrahi yöntemi literatür eşliğinde sunuyoruz.

Anahtar kelimeler: psödokist, çocuklar, ileum 


\section{INTRODUCTION}

Intraabdominal cysts and pseudocysts are unusual lesions [1]. This was noticed in 1507 by the Italian anatomist Benevenni when performing an autopsy in an 8-year-old child. In fact, 820 cases were reported in the literature by Tillaux, the first case in 1880 [2]. According to Kurtz et al., The incidence of the disease is approximately $1 / 100.000$, but other authors record a lower frequency, about 1 / 250.000 hospital applications. The disease is much more common in children under 10 years of age (1 patient per 4.000-34.000 hospital admissions) [1]. According to Kurtz et al., there was no difference in terms of gender and race. Mesenteric cysts are often asymptomatic [2], but sometimes patients may show symptoms such as abdominal pain or discomfort, abdominal distention, nausea, vomiting, bloating, constipation, or diarrhea [1]. Differential diagnosis required before each operation includes: peritoneal cyst, lymphangioma, endometriosis, acid, pancreatic pseudocyst, hemangioma, cystic mesenteric panniculitis, hydatid cyst, teratoma and urogenital cyst [1]. The surgical procedure recommended in the literature is the excision of the tumor [1]. Mesenteric cysts rarely recur after removal and patients have a good prognosis. The incidence of malignancy is about 3\% [1]. Rarely, these may be complicated by rupture or intestinal obstruction [2]. The intestinal volvulus caused by the mesenteric cyst typically affects children with acute abdominal symptoms [2]. The most common locations of mesenteric cysts are: small intestine mesentery (50-80\%) and then right colon and large intestine mesentery (15-30\%) [1]. The size of mesenteric cysts varies from a few centimeters to $10 \mathrm{~cm}$. Cysts larger than $10 \mathrm{~cm}$ are defined as giant mesenteric cysts. The exact etiology of mesenteric cysts is unknown [2]. Clinical imaging methods (Ultrasound, Computed tomography or Magnetic resonance imaging) can help in reaching a definitive diagnosis [2]. Mesenteric cysts in the pediatric age group are more common in boys (62.5\%) and most cases are younger than 10 years old [3].

\section{CASE REPORT}

This report presents a male patient with an open approach operated intra-abdominal cyst and nonspecific symptoms. The patient was 11 years old and was admitted to Karaman State Hospital Pediatric Emergency Clinic with cramp-like abdominal pain and nausea and vomiting for two days. In addition, the patient complained of fever $\left(38^{\circ} \mathrm{C}\right)$ and anorexia. The patient's history included a laparoscopic appendectomy history performed at a private medical center a year ago. As a laboratory finding, neutrophilia and leukocytosis were present. In the physical examination, there was widespread sensitivity in all the quadrants of the abdomen. There were several lymph nodes in the lower quadrant of the mesentery with a short anterior width of 8 $\mathrm{mm}$. In addition, there was no abnormality in the intraabdominal organs except for a $9 \mathrm{~mm}$ diameter nodular lesion in the left adrenal region. The abdomen was explored with a midline incision on the navel passing through the right side of the abdomen. Adhesions between the bowel loops in the distal of the ileum were opened with blunt dissection and scissors. With an $8 \mathrm{~cm}$ bowel loop, excision was performed and an ileoileal resection anastomosis was performed to ensure bowel continuity.

Microscopic examination of the excised cyst showed active chronic inflammation, edema, granulation tissue, mesenteric pseudocyst (Figures 1-3). The cyst of our patient was classified as a mesenteric pseudocyst with first class content according to Beahrs et al., Ros et al., and de Perrot et al. Most such lesions are associated with a post-traumatic or inflammatory event. Abdominal trauma has not been reported in our patient. The patient's history of laparoscopic appendectomy a year ago suggested an inflammatory event in the abdominal wall of this lesion. The patient had a uneventful course after surgery and was discharged 7 days after the operation. Six weeks later, the patient was asymptomatic.

\section{DISCUSSION}

Mesenteric cysts have a good prognosis and no recurrence has been observed following complete excision of the cyst [4]. Recently, Ros et al. reviewed 41 cases of mesenteric and omental cysts and proposed another histological classification related to radiological findings. They divided the cysts into five groups:

Lymphangiomas, enteric duplication cysts, enteric cysts, mesothelial cysts, non-pancreatic pseudocysts (they used the term "pseudocysts" for the first time in the classification of mesenteric cysts).

The final classification of intra-abdominal cysts was formed by Perrot et al. [4] in 2000 based on the histological identity of the inner epithelium and consists of 6 groups:

- Lymphatic cysts: simple cyst and lymphangioma (the only exception that usually occurs in the first decade of life (up to 12 years of age) with male dominance) [4];

- Mesothelial cysts: Malignant mesothelioma, simple cyst, benign mesothelioma (this is often associated with a previous pelvic inflammatory process or history of surgery and endometriosis) [4];

- Urogenital cyst;

- Mature cystic teratoma (dermoid cysts); 


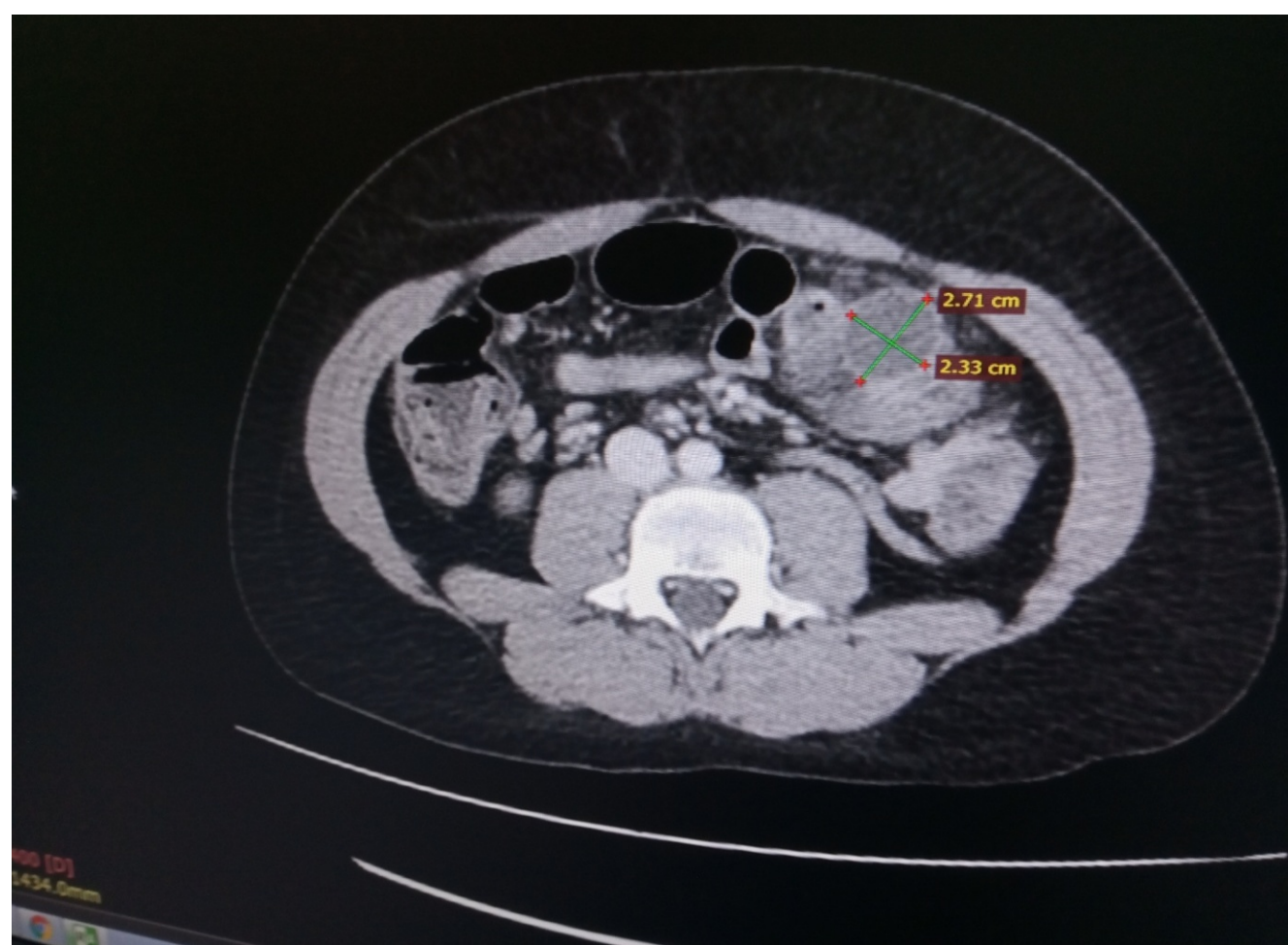

Figure 1. Pseudocyst formation in ileum in contrast-enhanced CT (measuring $2.71 \times 2.33 \mathrm{~cm}$ )

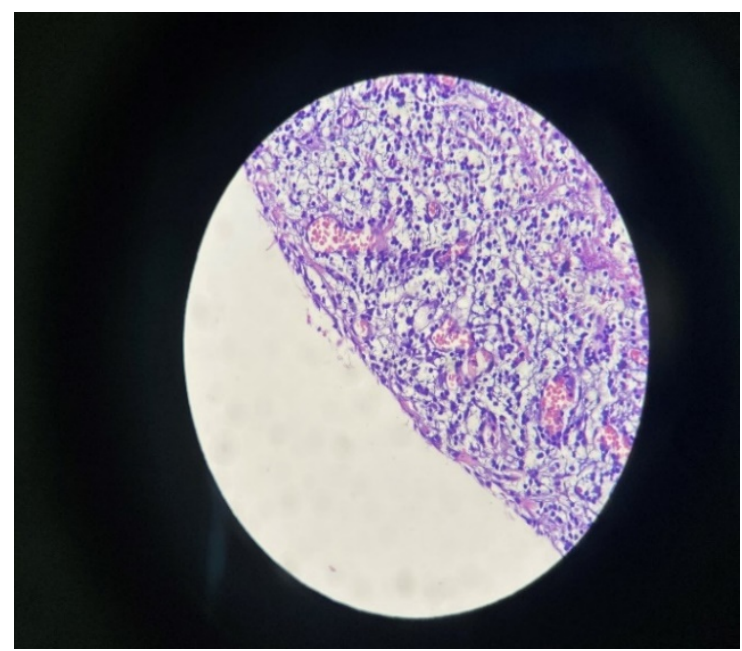

Figure 2. Multiple pseudocyst formations in seroza ( $x 40, H$ \& $E)$

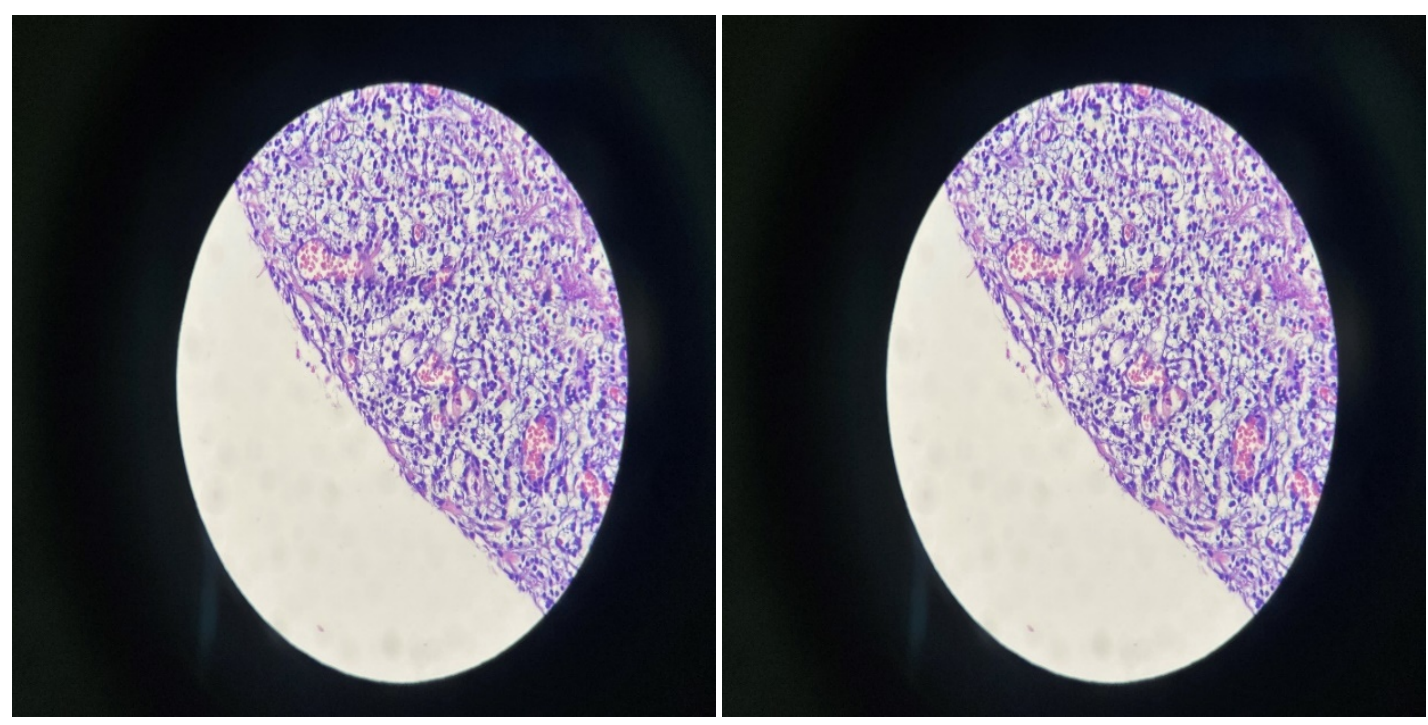

Figure 3. Pseudocyst surface $(x 200, H \& E)$ covered with foamed histiocytes, not observed in epithelium 
- Pseudocysts (inflammatory, traumatic and degenerative). Mesenteric pseudocysts are called nonpancreatic pseudocysts to prevent confusion with the much more common pancreatic pseudocyst [5]. Nonpancreatic pseudocysts are masses without an internal cellular main membrane; they are considered to be a non-absorbent mesenteric or omental hematoma or abscess sequel. It has nothing to do with pancreatitis. Pathologically, pseudocysts are thick-walled, usually hemorrhagic or purulent-containing separated cystic masses [5].

Sonographically, a hypoechoic mass often appears filled with echogenic dead tissues. Computed tomography (CT) and Magnetic resonance (MR) imaging reveals a thickwalled cystic mass that may contain an air-fluid level resulting from hemorrhagic or purulent contents and does not show an increase after contrast [6]. Non-pancreatic pseudocysts have a fibrous wall with no epithelium and a serous (pale yellow) or mucoid (brownish red) content. Their origin may be inflammatory or traumatic [7].

Mesenteric pseudocysts are difficult to diagnose because they exist as a lost mass or in a changing place [8]. In general, the patient has no symptoms and the cyst is discovered by chance in imaging the abdomen for other reasons. Larger lesions are abdominal pain, discomfort, distension, or other nonspecific symptoms [8].

In our case, the diagnosis revealed a defined collection of abdominal pain and vomiting complaints that occurred after laparoscopic appendectomy the first presentation was made a year ago and increased for several days until clinical presentation and imaging. Mesenteric pseudocysts may be secondary to trauma or infection [9] and the internal appearance of the cyst etiology is secondary to inflammation between bowel loops in this patient.

In our case, there was an inflammatory infiltration and an infectious cause was possible because the patient had no history of trauma. Treatment is surgical resection, as in $3 \%$ of cases, the only way to prevent the lesion from turning into a malignant mesenteric cyst [9].

\section{CONCLUSION}

The case we reported came to the operating table without a proper diagnosis of the disease. Diagnostic imaging methods may allow accurate diagnosis, but it is not always possible to solve the diagnostic problem due to the rarity of the lesion.

\section{DECLARATION OF CONFLICT OF INTEREST}

The authors received no financial support for the research and/or authorship of this article. There is no conflict of interest.

\section{REFERENCES}

1. Kurnicki J, Swiatkiewicz J, Wrzesinska N, Skorski M. Laparoscopic treatment of a huge mesenteric pseudocyst - case report. Video surgery andothermini invasive techniques. 2011; 6(3): 167-72. (doi: 10.5114/wiitm.2011.24696).

2. Goyal S, Verma RK, Singh SP, Ahsan MM. Mesenteric cyst of transverse mesocolon: a rare case of report and review of literature. Arch Clin Exp Surg. 2013; 2: 200-3. (doi: 10.5455/aces.20120217091826).

3. Prakash A, Agrawal A, Gupta RK, Sanghvi B, Parelkar S. Early management of mesenteric cyst prevents catastrophes: a single centre analysis of 17 cases. African Journal of Pediatric Surgery. 2010; 7(3): 140-3. (doi: 10.4103/0189-6725.70411).

4. Bhandarwar $A H$, Tayade MB, Borisa AD, Kasat GV. Laparoscopic excision of mesenteric cyst of sigmoid mesocolon. Journal of Minimal Access Surgery. 2013; 9(1): 37-9. (doi: 10.4103/0972-9941.107138).

5. Çizginer S, Tatlı S, Snyder EL, Goldberg JE, Silverman SG. CT And MR Imaging Features of a Non-Pancreatic Pseudocyst of the Mesentery. Eur J Gen Med. 2009;6(1):49-51. (doi: 10.29333/ejgm/82637).

6. Stoupis C, Ros PR, Abbitt PL, Burton SS, Gauger J. Bubbles in the belly: imaging of cystic mesenteric or omental masses. Scientific Exhibit. 1994; 14(4): 729-37. (doi: 10.1148/radiographics.14.4.7938764).

7. Gallego JC, Gonzalez JM, Fernandez-Virgos A, del Castillo M. Retrorectal mesenteric cyst (nonpancreatic pseudocyst) in adult. European Journal of Radiology. 1996; 23: 135-7. (doi: 10.1016/0720-048X(96)01024-8).

8. Bhullar JS, Orfanou P. The disappearing abdominal mass: mesenteric pseudocyst. JSLS 2014; 18: 319-22. (doi: 10.4293/108680813X13753907290991).

9. Park SE, Jeon TJ, Park JY. Mesenteric pseudocyst of the transverse colon: unusual presentation of more common pathology. BMJ Case Report Jan 2016. (doi: 10.1136/bcr2013-202682). 